\title{
"Reform or revolution"? Polanyian versus Marxian perspectives on the regulation of the economic
}

\author{
GRIETJE BAARS ${ }^{1}$ \\ University College London/City University London
}

\begin{abstract}
Rosa Luxembourg's 1900 pamphlet "Reform or revolution", which critiqued reformist political strategy, has relevance to, and finds echoes in today's debates on the possibility and desirability of using law to protect society from the market's negative effects. It also summed up the nineteenth-century "Polanyian" reformist and Marxist "revolutionary" perspectives. Polanyi argued that "the economic" must be "embedded" in the social by means of legal regulation, an argument he illustrates with the help of the "Speenhamland" example. Marx, while acknowledging the role of the legal struggle as part of class struggle, concludes that ultimately "right can never be higher than the economic structure of society". Marxist legal theorist Pashukanis developed this position in his "commodity form theory of law" which points to the structural impossibility of law's regulation of capitalism. While contemporary "Polanyist" Ruggie again asserts that legal and soft law "global governance" regimes can control capitalism's main instrument, the corporation, Shamir contra Ruggie argues that the "moralisation of markets" through corporate social responsibility (CSR) leads to the "marketisation of morality" or a change in what we perceive law to be (and who has legitimate authority to regulate) rather than a "taming" of markets. Following Shamir, I add that this corporate-led global governance hastens the collapse of capitalism, and confirms the inevitability of revolution and the subsequent creation of a law-free society.
\end{abstract}

\section{Introduction}

$\mathrm{I}^{\mathrm{n}}$ n her 1900 pamphlet "Reform or revolution", Rosa Luxemburg made short shrift of her contemporary Eduard Bernstein's reformist theory - in which he argues that socialdemocrats must abandon the idea of revolution, and instead work towards the betterment of the situation of the worker, and increased social control of the economy within the capitalist framework. "Bernstein, proposing to change the sea of capitalist bitterness into a sea of socialist sweetness, by progressively pouring into it bottles of social reformist

$1 \quad \mathrm{PhD}$ Candidate, University College London (submission expected December 2011); lecturer, City University London. I am grateful to Kamil Majchrzak, Ronen Shamir, China Miéville, Catherine Redgwell, Stephen Guest, Sonja Buckel, Joel Shalit, Jason Beckett and the anonymous reviewers for their many helpful comments and suggestions, to Dr Bettina Lange and Dr Dania Thomas for inviting me to participate in the Oxford CSLS workshop and publication. All errors and omissions remain mine alone.

2 Bernstein presented this theory in his series of articles "Problème des Sozialismus" in the magazine Die Neue Zeit, edited and published by Karl Kautsky, 1896 onwards, and his book Die Voraussetzungen des Sozialismus und die Aufgaben der Sozialdemokratie (Berlin: Dietz Verlag 1991). 
lemonade, presents an idea that is . . . insipid [and] fantastic" Luxemburg concludes. ${ }^{3}$ Bernstein's position is closely related to that of Polanyi, while Luxemburg was a "wholehearted Marxist". ${ }^{4}$ In this article, I analyse Polanyian and Marxist perspectives on the (legal) regulation of "the economic". Bernstein's "lemonade" is legal measures aimed at constraining market actors so as to minimise capitalism's negative effects on society. Polanyi also argues that law is required (and adequate) to subject the market to the needs of society. Here I will argue, with Luxemburg and Marx, that subjecting the market to society through law is a structural impossibility, and that nothing less than revolution will achieve the ends envisaged by Polanyians and Marxists alike.

In section two, I examine Polanyi's discussion on the "Speenhamland system": one of the legal measures to curb the extreme poverty resulting from the creation of the free market in seventeenth-century England. In Polanyi's The Great Transformation, his discussion of Speenhamland illustrates his general attitude to legal regulation of the market. In section three, I set out Marx's discussion of the eighteenth and nineteenth-century legal regulation of the length of the working day, which in turn illustrates Marx's attitude to the use of law in a capitalist society. There then follows a discussion of further works by Marx, Engels, Luxemburg and Pashukanis to complete the Marxian picture on the utility of law in emancipatory struggle and also post-capitalism. In section four I demonstrate the debate's contemporary relevance and analyse a Polanyian take on the regulation of the economy, and specifically the corporation, as exemplified by John Ruggie in his academic work as well as his position as UN Special Representative on Business and Human Rights. His approach is critiqued by Shamir - discussed in section five. Finally, in section six, I take a closer look at the identity of society and the agents of change in each perspective. I return to Rosa Luxemburg and this article's title "Reform or revolution?" to draw conclusions on regulation of the economy through law.

\section{Karl Polanyi: The Great Transformation}

\section{POLANYI'S SPEENHAMLAND}

The main example of "social regulation" in which Polanyi's theoretical argument is anchored is the Speenhamland system. In Polanyi's idiosyncratic ${ }^{5}$ account of the transition to, and maturing of, European capitalism in The Great Transformation, Speenhamland is key: in Polanyi's view, "few institutions have shaped the fate of a whole civilization more decisively than this". 6

The British Speenhamland system was devised in 1795 as a response to widespread poverty following the forcible uprooting of the poor from their countryside abodes in the enclosure regime - a process ongoing since the Tudor period that saw the division of commons land into private property, with the dual aim of increasing agricultural production (through e.g. mass sheep-farming instead of self-sufficiency and cottage industry) and the creation of a class of landless poor who would be employed in the newly developing

3 R Luxemburg, "Reform or revolution" in H Scott (ed.), The Essential Rosa Luxemburg: Reform or revolution and the mass strike (Chicago: Haymarket Books 2008), p. 65.

4 J P Nettl, Rosa Luxemburg vol. I (London: OUP 1966), p. vii.

5 Polanyi offers unique definitions for commonly used terms such as "market" (p. 59), "commodity" (p. 75), "exploitation" (p. 42), the "division of labour" (p. 46), etc. which sets his work apart from Smithian economists as well as Marxist scholars: K Polanyi, The Great Transformation: The political and economic origins of our time 2nd edn (Boston: Beacon Press 2001).

6 Ibid. p. 90. 
industries. ${ }^{7}$ Probably the best-known account of this process is E P Thompson's The Making of the English Working Class. ${ }^{8}$

According to Thompson, "[e]nclosure (when all the sophistications are allowed for) was a plain enough case of class robbery, played according to fair rules of property and law laid down by a parliament of property-owners and lawyers".? The historian Merriman contextualises Speenhamland within a tightening (legal) regime of social control to stem growing lower-class restiveness and to prevent the influence of the French Revolution of 1798, and later the European revolutions of 1848, from "blowing over" to Britain. ${ }^{10}$ A poor support system had been available since the early eighteenth century, including the "old" Elizabethan Poor Law (an indirect response to the cessation of grain imports from France after British involvement in French wars), which included parishes and townships providing charity to those wearing a badge with the letter "P" for pauper. ${ }^{11}$

The Speenhamland system was a different kind of system, with parishes providing topup wages to working poor to the level of the price of two loaves of bread per week per worker. ${ }^{12}$ It thus tied wages to the price of wheat while the price of wheat (and the availability of wheat for consumption) fluctuated with the quality of the harvest and market manipulation by traders stockpiling wheat for future sales. One effect of the system was that it encouraged employers to pay low wages in the knowledge these would be topped up. ${ }^{13}$ Eventually, after a report by the Royal Commission of the Poor Law, which accepted the view that the system interfered with the market, the Poor Law Amendment Act of 1834 abolished the system and replaced it with workhouses, which at their high point in 1841 held more than 200,000 people incarcerated in Britain. ${ }^{14}$

Polanyi presents the enclosure process (which, he notes, was also called a "revolution of the rich against the poor") ${ }^{15}$ as a (non-)choice between "habitation or improvement". ${ }^{16}$ While he recognises the "avalanche of social dislocation"17 this process brought about, as well as the "wholesale destruction of the traditional fabric of society", 18 the improvement

7 Enclosures are also described by (amongst others) Marx - who defines them as an essential precursor to capitalism termed "primitive accumulation" - and which we see occurring also in the colonies during the nineteenth and twentieth centuries, e.g. the Congo as described by Renton and Zeilig, in D Renton, D Seddon and L Zeilig, The Congo: Plunder and resistance (London: Zed Books 2006); for enclosure and resistance in the twenty-first century, see, e.g., the work of the Movimento dos Trabalhadores Rurais Sem Terra www.mst.org.br/ (last accessed 1 September 2011).

8 E P Thompson, The Making of the English Working Class (London: Penguin 1963).

9 Ibid. pp. 237-8.

10 For example, in 1723 the British Parliament passed a law that added 50 capital offences against property, including poaching, gathering of firewood, etc., from land that had been the common source of sustenance before enclosures. The role of, and attitude to, law in the enclosure process is summed up in the folk rhyme of the time: "They hang the man, and flog the woman, That steals the goose from off the common; But let the greater villain loose, That steals the common from the goose." See, generally, J Merriman, A History of Modern Europe: From the renaissance to the present 3rd edn (New York: W W Norton \& Company 2010), pp. $382 \mathrm{ff}$.

11 Ibid. p. 383.

12 The Speenhamland system is named after the parish of Speenhamland in Berkshire, where it was conceived. Additional wages could be paid for children, and also for clothing, unless such was supplied by the employer or the parish directly. The system was funded through "poor rates", which were property taxes collected from landowners.

13 Merriman, A History, n. 10 above, p. 559; see also, Thompson, The Making, n. 8 above, pp. 247-8.

14 Merriman, A History, n. 10 above, p. 559.

15 Polanyi, The Great Transformation, n. 5 above, p. 37.

16 Ibid. p. 35

17 Ibid. p. 42

18 Ibid. p. 81 
in agricultural yield, including the increased wool production which eventually led to the development of the cotton industry - the catalyst for Britain's Industrial Revolution - made it worth the sacrifice. ${ }^{19}$

Even so, the fulfilment of the capitalist utopia of the free market was prevented. Polanyi states, "[e]ighteenth-century society unconsciously resisted any attempt at being made into a mere appendage of the market". ${ }^{20}$ By the implementation of the Speenhamland system, Polanyi argues, society effectively prevented the establishment of a free market for labour. However, the main failure of Speenhamland came with the realisation that "nobody would work for a wage if he could make a living doing nothing". ${ }^{21}$ In addition, "no labourer had any financial interest in satisfying his employer, his income being the same whatever wages he earned". ${ }^{22}$ Within a few years, the labour of paupers "became indistinguishable from 'boondoggling' or the semblance of work maintained for the sake of appearances". 23 Thus, it was concluded that a regular labour market had to be established, and "mankind was forced into the paths of a utopian experiment". 24

Elsewhere Polanyi speaks of an emotional awareness of the individual and his or her role in larger society, "the discovery of society", and the moral or emotional effect of Speenhamland: "the dehumanization of the masses began to paralyse national life, and notably to constrain the energies of industry itself". 25 This awareness appealed to the liberal sensitivity and self-image of the emerging middle class. While the law was considered "squirearchy's" (landowners') last attempt to prevent the advent of a new order, "[t]he abolishment of Speenhamland [in 1832] was the true birthday of the modern working class, whose immediate self-interest destined them to become protectors of society against the intrinsic dangers of a machine civilization".

The year 1832 was of course also the year of the Reform Act, which produced farreaching electoral reforms including eliminating the so-called "rotten borough" and "pocket boroughs" and effectively giving the middle class a majority in Parliament. ${ }^{26}$ As such, "[t]he repeal of Speenhamland was the work of a new class entering onto the historical scene, the middle classes of England". Furthermore, in 1832 the English Industrial Revolution was about to enter its most productive phase. Enterprise and industry, the traditional realms of the middle classes, were about to increase exponentially. The new Poor Law Amendment Act "assumed a labouring class which ... was forced to give its best under the threat of hunger, so that wages were regulated by the price of gain". ${ }^{27}$ The middle-class dependence on the labour of the working class made the working class the moral protector of bourgeois society, and the legitimiser of its authority.

19 Polanyi, The Great Transformation, n. 5 above, pp. 39-40. Polanyi thus cites agricultural efficiency as the sole purpose of the enclosure system, unlike Merriman, Marx and Thompson.

20 Ibid. p. 81.

21 Ibid. p. 82.

22 Ibid. p. 83.

23 Ibid. p. 83.

24 Ibid. p. 85.

25 Ibid. p. 102.

26 An Act to Amend the Representation of the People in England and Wales, short title: Representation of the People Act 1832 (2 \& 3 Wm IV, c. 45); Merriman, A History, n. 10 above, p. 592.

27 Polanyi, The Great Transformation, n. 5 above, pp. 144-5. 


\section{POLANYI ON "EMBEDDEDNESS"}

Law continued to play an important role in "market society" after the English "bourgeois revolution". ${ }^{28}$ Polanyi discusses the protectionism that enabled British industry to develop, the centralisation of banking through Peel's Bank Act of 1844 and the creation of an effective policing system and regime of criminal law needed for social control. ${ }^{29}$

Aside from the market requiring law, any attempt at disembedding the economic from society would result in measures taken by society to protect itself. Polanyi's concept of "embeddedness" expresses the idea that the economy cannot (or should not be) ${ }^{30}$ selfregulating but must be subordinated to politics and social relations. ${ }^{31}$ Polanyi argued that market society is unsustainable because it is fatally destructive to the human and natural contexts it inhabits. ${ }^{32}$ By his oft-cited statement "[1]aissez faire was planned; planning was not", Polanyi means that these measures are spontaneous, ad hoc. But despite legislative acts adopted to manage problems arising out of modern industrial conditions (including, for example, "public health, factory conditions, municipal trading, social insurance, shipping subsidies, public utilities, trade associations, and so on"), liberal capitalism was also to fail in the early twentieth century. ${ }^{33}$

\section{Collapse AND REVIVAL?}

In Polanyi's view, the attempt to organise high finance along the model of market liberalism through the Gold Standard led directly to both World Wars and the Great Depression. ${ }^{34}$ Rothschilds and J P Morgan are accredited with a particular role, although they could be seen as pars pro toto for the undoubtedly much larger sector. The failure included not dealing adequately with the international aspect of high finance:

The Rothschilds were subject to no one government; as a family they embodied the abstract principle of internationalism; their loyalty was to a firm, the credit of which had become the only supranational link between political government and industrial effort in a swiftly growing world economy. 35

Writing during the Second World War (The Great Transformation was published in 1944), Polanyi argued that what is needed for a sustainable market-based system is that labour, land and money be "taken out of the market" and regulated by the state. Crucially, he does not give further details of what such regulation might entail - leading to the conclusion that social regulation must remain spontaneous, and reflect the liberal values inhering in society at a given point. Since Polanyi's thesis is that state regulation of the "economic" is required and desirable, the fact that he anchors his thesis in two main examples of failed regulation may seem odd. However, both examples were defective in Polanyi's mind in that their aim had not been to protect "the social", but particular interests: the interests of the squirearchy in the first example, and US interests in the second. Below I argue that Polanyi's conception of "the social" also reflects a particular section of society, namely the middle class, but first I examine the working class in relation to regulation of the economic.

28 Polanyi, The Great Transformation, n. 5 above, p. 145.

29 To this should be added, that "capitalism's main bearer" or "engine" is of course also a creature of law.

30 Polanyi wavers between arguing that the economy cannot, and should not, be separated from society, which has given rise to arguments over the correct interpretation of his work: F Block, "Introduction" in Polanyi, The Great Transformation, n. 5 above, p. xxiv.

31 Block, "Introduction", n. 30 above, p. xxvi.

32 Polanyi, The Great Transformation, n. 5 above, p. 3.

33 Ibid. p. 153.

34 Generally, ibid. pp. 11-32.

35 Ibid. pp. 11-12. 


\section{Karl Marx and Marxist approaches to the regulation of "the economic"}

\section{MARX ON THE LENGTH OF THE WORKING DAY}

Marx said, unless society forces capital, it will not improve the conditions of labour. Any change in the appalling labour conditions pertaining in the British factories of the time which included children as young as seven working 16-hour days - like change in general, is achieved through class struggle. ${ }^{36}$ In Chapter 24 of Capital vol. I, Marx analyses the eighteenth and nineteenth-century legal regulation of the length of the working day, which reflects His assessment of the role of law in capitalist society. ${ }^{37}$

Marx relates how "centuries of 'civil war' between capital and labour" have led to concessions made by capital in favour of workers. At times this has occurred because of labour shortage. ${ }^{38}$ Once a concession is made and "enacted" in legislation, another struggle ensues over enforcement, ${ }^{39}$ where the capitalist may insist on enforcement in order to avoid competition from "false brethren" - the insistence on a "level playing field". 40

At other times the capitalist class would agree to compromise in return for a concession on another issue before Parliament. Capital found various ways to compensate for these concessions with economic violence, for example, through responding to a legal limit on the working day (the Ten Hour Act) with a reduction in wages - such that workers would then advocate the repeal of the law that had been passed in their favour. ${ }^{41}$

Enforcement increasingly became a battle between factory inspectors and magistrates. Marx describes one example where the magistrates rule on a particular alleged violation brought by a factory inspector - the magistrates themselves being, like the defendants, powerful cotton-spinners. ${ }^{42}$ Dependence on the factory inspectors for enforcement also meant the workers had no direct access to legal mechanisms of redress. As Marx put it, "[t]he isolated worker succumbs" 43 - for this reason, Marx concludes:

For "protection" against "the serpent of their agonies" the labourers have to put their heads together, and, as a class compel the passing of a law, an all-powerful social barrier that shall prevent the very workers from selling, by voluntary contract with capital, themselves and their families, into slavery and death. In place of the pompous catalogue of the "inalienable rights of men" comes the modest Magna Carta of a legally limited working-day, which shall make clear "when the time which the worker sells is ended, and when his own begins". 44

This gives the superficial impression that Marx has substantial faith in law's emancipatory potential. From Marx's other writing we learn that this was not the case, and that his call for "an all-powerful social barrier" should be understood rhetorically. As Marx was eminently aware, and as Chris Arthur has surmised:

36 K Marx and F Engels, Manifesto of the Communist Party (Moscow: Progress Publishers 1977), p. 40.

37 K Marx, Capital: A critique of political economy vol. I (London: Penguin 1976).

38 Ibid. p. 383.

39 Ibid. p. 392.

40 Ibid. p. 393.

41 Ibid. pp. 396-7.

42 Ibid. p. 401.

43 Ibid. p. 412.

44 Ibid. p. 416. The "modest Magna Carta" may refer to the efforts of the Chartist movement, the mass petition movement for universal suffrage, which, at the moment when other European countries were enacting their revolutions, was forcefully repressed in Britain. Merriman, A History, n. 10 above, p. 642. 
No amount of reformist factory legislation can overcome the basic presupposition of the law: that a property freely alienated belongs to the purchaser, and hence that the living labour of the worker becomes, through exchange, available for exploitation by capital. ${ }^{45}$

\section{MarXism AND the Debate on “LAW's emanCiPatory potential”}

As indicated above, Marxists are divided on the "emancipatory potential" of law, or, more generally, on the utility of law in class struggle or for the purpose of social regulation. Marx and Engels themselves did not provide an explicit theorisation of the role of law in society, although they include analyses in various texts. ${ }^{46}$

Some Marxists take a purely "functionalist" view of law, where law is conceived as the direct embodiment of the interests of the ruling class, ${ }^{47}$ while others follow Pashukanis in his view that not merely the content, but also the form of law is inherently capitalist. ${ }^{48}$ Marxist legal theorists such as Pashukanis and Stuchka date the origin of "bourgeois law" exactly to "primitive accumulation" (Marx's term for the private appropriation of commons land in the enclosure period occurring throughout Europe) ${ }^{49}$ and the capitalist mode of production: the time when man comes to be seen as a legal person, the bearer of rights, who can engage in market transactions with other subjects as a formal legal equal. Pashukanis approximates the legal form to the commodity form. ${ }^{50}$

Miéville summarises the "commodity-form theory of law" as follows: "Law is a relation between subjects abstracted of social context, facing each other in a relationship predicated on private property, dependent on coercion." 51 Coercion and violence are inherent in the legal form as the notion of "mine" necessary to ownership and commodity exchange is only meaningful inasmuch as it is "mine-not-yours". 52 Capitalist law was "universalised" in the transition to capitalism: the rise to dominance of the bourgeoisie and the demise of the feudal system. ${ }^{53}$ The rise of capitalism in Europe generally coincided with the advent of parliamentary democracy, through which - after the 1832 Reform Act - the bourgeoisie eventually gained political as well as economic control. The bourgeois state is described by

45 C Arthur, "Introduction" in E B Pashukanis (ed.), Law and Marxism: A general theory 1st edn (translation of 2nd edn published in 1926) (London: Ink Links 1978), p. 31.

46 Cain and Hunt provide a useful compendium of texts in which Marx and Engels deal with law: M Cain and A Hunt, Marx and Engels on Law (London: Academic Press 1979).

47 Ibid. pp. $x-x i$.

48 Pashukanis, Law and Marxism, n. 45 above; C Miéville, Between Equal Rights: A Marxist theory of international law (London: Pluto 2006); R Knox, "Marxism, international law and political strategy" (2009) 22 Leiden Journal of International Law 413.

49 Marx, Capital, n. 37 above, "Part eight: so-called primitive accumulation", pp. $873 \mathrm{ff}$.

50 The latter point became the main difference between Pashukanis and Stuchka, who accuses Pashukanis of "economism" and holds that not all law is necessarily bourgeois law, but law is "class law" based on the will of the dominant class, and there is thus a possibility for proletarian law. P Stuchka, "State and law in the period of socialist construction" in R Sharlet, P Maggs and P Byrne (eds), Selected Writings on Soviet Law and Marxism (Armonk: M E Sharpe 1988), pp. 180-1. Pashukanis later (pragmatically or otherwise) came around to the necessity of law in the Soviet Union but eventually became a victim of one of Stalin's purges.

51 Miéville here speaks about international law, but the analogy applies to domestic law (any law) also. Miéville, Between Equal Rights, n. 48 above, p. 318. On the salience of a distinction between national and international law from a Marxist perspective (and taking a different view from Miéville), see A Rasulov, “The nameless rapture of the struggle: towards a Marxist class-theoretic approach to international law" (2008) 19 Finnish Yearbook of International Law 243, p. 259.

52 Miéville, Between Equal Rights, n. 48 above, p. 95, at n. 99.

53 For a more elaborate discussion of this process, see G Baars, Law Congealing Capitalism: On the (im)possibility of restraining business in conflict through international criminal law, $\mathrm{PhD}$ thesis expected submission December 2011, University College London. 
Marxists as a "committee for managing the affairs of the middle class" 54 and an "ideological smokescreen to conceal [ruling class] hegemony". 55

\section{Legal struggle as class struggle}

In the examples given by Marx in his chapter on the working day, the workers' struggle was a matter of survival - this is also acknowledged by Polanyi above - as according to the theory of surplus value the capitalist will seek to increase his profit by maximising "exploitation", that is, the extraction of surplus value from the worker through keeping her/him in work for the longest time possible at the lowest possible wage. While the "physical" limit on the working day lay at around 18 hours for adults, any further reduction was achieved through class struggle. Workers withheld their labour, resisted by means of strikes when the balance of collective bargaining was in their favour.

At other times power was not in their favour, as in the Ten Hour Act example above. A legislative Act in itself is also but one step, when enforcement of the legal provisions, or their avoidance, or amendment form new sites for struggle.

Class struggle through law has defined limits. According to Luxemburg:

Trade unions cannot suppress the law of wages. Under the most favourable circumstances the best they can do is to impose on capitalist exploitation the 'normal' limit of the moment. They have not, however, the power to suppress exploitation itself, not even gradually. ${ }^{56}$

At the same time, law is used both to predict (or, make predictable) and contain class struggle:

The juridical axiomatic ... allows political forecasting on the part of the dominant classes: while it expresses a class relationship of forces, it also serves as a prop for strategic calculation by including among the variables of its system the resistance and struggle of the dominated class. ${ }^{57}$

Rosa Luxemburg's critique of Bernstein's programme is that he sees reform, including legal reform, as an end rather than a mere tactic. Like Polanyi, Bernstein believes a state of "freedom" can be achieved through reformist legal regulation and control, such that a revolution becomes redundant. Luxemburg's argument that this is not possible reflects Marx's "Critique of the Gotha programme" 58 and Engels' and Kautsky's critique of "juridical socialism" which are themselves critical commentaries on "reformist" political programmes. ${ }^{59}$ In short, law's form precludes its emancipatory potential.

\section{Pragmatism, tactics and realism}

Some Marxist legal scholars argue for "principled opportunism”, i.e. the use of law/legal struggle tactically when a window of opportunity opens. ${ }^{60}$ Thus, legal struggle and social regulation can improve the circumstances of the workers and others in the short term or on an individual basis. Again, it can only do so within the parameters set by the current

54 Marx and Engels, Manifesto, n. 36 above, p. 44.

55 Pashukanis, Law and Marxism, n. 45 above, p. 140. For more recent analyses, see, e.g., N Poulantzas, State, Power, Socialism (London: Verso 1978).

56 Luxemburg, "Reform or revolution", n. 3 above, p. 56.

57 Poulantzas, State, Power, Socialism, n. 55 above, p. 92.

58 K Marx, "Critique of the Gotha programme" in D McLellan (ed.), Karl Marx, Selected Writings, 2nd edn (Oxford: OUP 2000), pp. 610-16.

59 F Engels and K Kautsky, "Juridical socialism" (1977) 7 Politics and Society 203; and see also, P Beirne, "Introduction" (1977) 7 Politics and Society 199.

60 Knox, "Marxism, international law and political strategy", n. 48 above, p. 433. 
mode of production, and as such it will amount to "attacking the twigs of the tree" 61 or "tinkering on the surface". ${ }^{62}$ Such opportunism may indeed also serve to legitimate the current system, form a "pressure valve" for capitalism and thus be undesirable on strategic grounds, if a move away from the current system is indeed the aim.

Ultimately, what such a move necessitates is abandoning our "juristische Weltanschanung" ("juridical world view"), including liberal conceptions of right and justice which are generated by the capitalist mode of production. ${ }^{63}$ Weighing against this perspective is the consideration that the legal struggle may function as a site for the development of class consciousness and practice in social organisation (unions as a precursor to socialism, cooperative worker-owned factories as simulations for the post-capitalist age, etc.). ${ }^{64}$ Conversely, for lawyers and professional politicians, the concealment of economic facts (material reality, material inequality) by juridical discourse (discourse structured and contained by law) may prevent a coherent overall understanding of society. ${ }^{65}$

The debate among Marxists is far from being resolved, but is to some extent academic in both senses of the word. ${ }^{66}$ While there is often a pragmatic need to use law defensively ${ }^{67}$ (and one could include survival/hardship struggles such as those over the length of the working day) in this, the range of possible outcomes of a juridical struggle is always determined by the parameters set by the capitalist legal system and the underlying power relations, ${ }^{68}$ and always forms only a part of a broader struggle. As per Marx, "Right can never be higher than the economic structure of society and the cultural development conditioned by it." 69

So, while Polanyi expresses the hope or expectation that society would legislate to protect against the worst excesses of the market, Marxists point toward the structural limitations on what can be achieved through law, being essentially a creation, and sine qua non of capitalism. Ruggie and Shamir in turn show us that this dilemma is still very relevant today.

\section{John Gerard Ruggie: bringing Polanyi into the twenty-first century}

\section{"EMBEDDED LIBERALISM"}

In a 1982 article in International Organization - which has since become "one of the most frequently cited sources in the study of international political economy"70 - John Gerard

61 Luxemburg, "Reform or revolution", n. 3 above, p. 82.

62 Miéville, Between Equal Rights, n. 48 above, p. 316.

63 Beirne, "Introduction", n. 59 above. Beirne describes this dominant bourgeois world view as "the secularisation of theology", p. 204).

64 See, generally, R Luxemburg, "Mass strike" in Scott (ed.), n. 3 above, pp. 111-81.

65 Beirne "Introduction", n. 59 above, p. 212 and at n. 206.

66 For an overview of different Marxist scholars' attitudes to law over the past four decades, see, P Ireland, "History, critical legal studies and the mysterious disappearance of capitalism" (2002) 65 Modern Law Review 120.

67 Elena Loizidou describes the dilemma, and its resolution through "parrhesia" of an anarchist in court, in her analysis of Emma Goldman's trial: E Loizidou, "Anarchism: this is what democracy looks like" (draft chapter, on file with author) in J Martel and J Casas Klausen (eds), How Not to Be Governed: Readings and interpretations from a critical anarchist left (Lanham: Lexington 2011).

68 See also, S Marks, "False contingency" (2009) 62 Current Legal Problems 1.

69 Marx, "Critique of the Gotha programme", n. 58 above, p. 615.

70 J G Ruggie, "Introduction” in J G Ruggie (ed.), Embedding Global Markets: An enduring challenge (London: Ashgate 2008), p. 1. 
Ruggie introduces the term "embedded liberalism". ${ }^{71}$ Ruggie (an international relations scholar attached to the Harvard Kennedy School of Government) ${ }^{72}$ by coining this term engendered a "Polanyi-revival" in the social sciences: inspiring many dozens of attempts to update Polanyi's insights for the late twentieth and early twenty-first centuries. ${ }^{73}$ Ruggie's "social constructivist" approach to the regulation of the economy also lies at the basis of the CSR regime which has developed in the past two decades and to which Ruggie contributed significantly in his function as the UN Special Representative on Business and Human Rights. The 1982 article was updated between 2002 and 2008, in particular to include the "corporate connection". 74

Ruggie uses "embedded liberalism" to describe the post-Second World Ward liberalism which in his view was different from the liberal capitalism that had gone before (and which, he agrees with Polanyi, had led to both World Wars and the Great Depression). ${ }^{75}$ The "embedded liberalism compromise" meant that "unlike the economic nationalism of the thirties, it would be multilateral in character; unlike the liberalism of the Gold Standard and free trade, its multilateralism would be predicated on domestic interventionism. ${ }^{76}$ The multilateral order that was developed after the Second World War gained acceptance as a result of

the extraordinary power and perseverance of the United States. But that multilateralism and the quest for domestic stability were coupled and even conditioned by one another reflected the shared legitimacy of a set of social objectives to which the industrial world had moved $^{77}$

Notably, Ruggie did not take up or discuss Polanyi's proposal to "take labour, land and money out of the market". ${ }^{78}$

\section{EMBEDDED LIBERALISM 2.0: THE CORPORATE CONNECTION}

Between 2002 and 2008 Ruggie developed an updated analysis of the state of "embedded liberalism" and introduced the "corporate connection". In the intervening 20-odd years, which saw "a new wave of globalisation broader and deeper than before", 79 a "global backlash" had occurred, not only against the multilateral financial institutions in amongst others the "Battle of Seattle", 80 but also against "capitalism's main bearer" the corporation. As in the latter half of the nineteenth century, the corporation becomes a major site for contestation, or indeed struggle. One of the causes of the backlash, aside from growing

71 J G Ruggie, "International regimes, transactions, and change: embedded liberalism in the postwar economic order” (1982) 36(Spring) International Regimes 379.

72 A survey in Foreign Policy magazine identified Ruggie as one of the 25 most influential international relations scholars in the United States and Canada: J Ruggie's biography on the Harvard University website: www.hks.harvard.edu/m-rcbg/johnruggie/bio.html (last accessed 9 May 2011).

73 Viz. other articles in this special edition.

74 J G Ruggie, "Taking embedded liberalism global: the corporate connection", Ralph Milliband Lecture, London School of Economics, 6 June 2002. The text of this lecture was published in a slightly longer form with the same title in Ruggie, Embedding Global Markets, n. 70 above.

75 Ruggie, "International regimes", n. 71 above, p. 392.

76 Ibid. p. 393.

77 Ibid. p. 398.

78 Ruggie, "Introduction", n. 70 above, p. 2.

79 Ibid. p. 4.

80 Ibid. p. 5. See further, generally, N Hertz, The Silent Takeover: Global capitalism and the death of democracy (London: Arrow 2002); R Broad (ed.), Global Backlash: Citizen initiatives for a just world economy (Lanham: Rowman \& Littlefield Publishers 2002). 
global wealth disparities, Ruggie asserts, is the "global imbalance in rule-making". ${ }^{81}$ What he means by this is the fact that

[t]hose rules that favor global market expansion have become more robust and enforceable in the last decade or two ... [while] rules intended to promote equally valid social objectives, be they labor standards, human rights, environmental quality or poverty reduction, lag behind and in some instances actually have become weaker. ${ }^{82}$

In Ruggie's scheme, in order to attain a "socially sustainable globalisation", therefore, (and to avoid the backlash of the "isms": protectionism, nationalism, terrorism), ${ }^{83}$ an "embedded legalism" must be generated: "a complex and evolving compromise between legalism and pragmatism, between rule- and power-based approaches". 84 As the "corporation is key to the embedded liberal compromise", 85 it makes sense that this enterprise lays its focus here.

\section{Ruggie as SpeCial Representative on Business and Human Rights: the corporate CONNECTION REALISED}

In 2005, Kofi Annan appointed John Ruggie to the position of Special Representative of the Secretary General on Human Rights and Transnational Corporations and Other Business Enterprises. ${ }^{86}$ Ruggie held many consultations with, and received thousands of submissions by, non-governmental organisations (NGOs), business leaders, elected representatives and academic experts of various disciplines. ${ }^{87}$

Ruggie's 2008 report, "Protect, Respect, and Remedy" which resulted from this process, rests on three pillars: the state duty to protect against human rights abuses by third parties, including business; the corporate responsibility to respect human rights (which in essence means to act with due diligence to avoid infringing the rights of others); and greater access by victims to effective remedy, both judicial and non-judicial. ${ }^{88}$ The Human Rights Council (HRC) unanimously welcomed the framework and renewed Ruggie's mandate for three years. ${ }^{89}$

After "promoting and operationalizing" the framework, in 2011 Ruggie published the "Guiding Principles on Business and Human Rights: Implementing the United Nations 'Protect, Respect and Remedy' Framework" 90 and has since published reports detailing

81 Ruggie, "Taking embedded liberalism global" in Embedding Global Markets, n. 70 above, pp. 233-4.

82 Ibid. p. 234.

83 K Annan, A Compact for the New Century, 31 January 1999 (UN Doc. SG/SM/6881) cited in Ruggie, "Introduction", n. 78 above, p. 5.

84 For this notion, see A Lang, "Reconstructing embedded liberalism: John Gerard Ruggie and constructivist approaches to the study of the international trade regime" in Embedding Global Markets, n. 70 above, p. 24.

85 Ruggie, "Taking embedded liberalism global", n. 81 above, p. 253.

86 Commission on Human Rights, Resolution 2005/69, 20 April 2005 (UN Doc. E/CN4/RES/2005/69).

87 Lists can be found on the Human Rights Council website: www.ohchr.org/EN/Issues/ TransnationalCorporations/Pages/SRSGTransCorpIndex.aspx (last accessed 3 September 2011).

88 Report of the Special Representative of the Secretary-General on the Issue of Human Rights and Transnational Corporations and Other Business Enterprises, John Ruggie, 7 April 2008 (UN Doc. A/HRC/8/5).

89 Report of the Working Group on an Optional Protocol to the International Covenant on Economic, Social and Cultural Rights on its Fifth Session, 18 June 2008 (UN Doc. A/HRC/RES/8/7).

90 Report of the Special Representative of the Secretary-General on the Issue of Human Rights and Transnational Corporations and Other Business Enterprises, 21 March 2011 (UN Doc. A/HRC/17/31). 
applications of the framework by various parties. ${ }^{91}$ The HRC unanimously adopted the guidelines in June 2011.92

Elsewhere I have contrasted the "respect, protect and remedy" framework with instances of corporate accountability from practice - including most notably the Nuremberg Trials of the industrialists after the Second World War. ${ }^{93}$ Considering that the US military tribunals at Nuremberg based their judgments on binding international law norms, Ruggie's substantively weaker, non-binding framework effectively morphs law into a (privatised) governance regime 94 (while remaining "bourgeois law" in Pashukanis' sense). A main part of the "Ruggie effect" is the shifting of our gaze from the individual businessperson to the abstract corporate entity, which is nevertheless constituted by the Ruggie framework as an aspiring liberal citizen. ${ }^{95}$

In addition, the framework's "guidelines for implementation" defer normative responsibility to a future moment at which the state may never arrive, while creating a chasm between those affected by corporate activity (and omission) and the locus of the remedy. Affected persons become dependent on (Western) cause lawyers, who (at best) transform their grievance into a negotiable claim for monetary compensation. Primitive accumulation (or, in David Harvey's term, accumulation by dispossession) ${ }^{96}$ and slave labour thus become quantifiable in terms of value and negotiable as between formal legal equals: the affected individual versus the Western multinational corporation. ${ }^{97}$

Despite Ruggie's own assessment of the failure of embedded liberalism highlighting the global imbalance of rule-making, his newly minted regime suffers from the same pathology. As such, it is unlikely to preserve or reinvigorate embedded liberalism. Instead, it tends more toward neoliberalism as described by David Harvey:

in the first instance a theory of political economic practices that proposes that human well-being can best be advanced by liberating individual entrepreneurial freedoms and skills within an institutional framework characterised by strong property rights, free markets and free trade. ${ }^{98}$

Harvey additionally asserts that "neoliberalism values market exchange as 'an ethic in itself, capable of acting as a guide to all human action, and substituting for all previously held ethical beliefs". 99 As such the "neo" in neoliberalism only refers to its temporal occurrence, and not to a new liberalism as such. Neoliberalism in Harvey's definition to all intents and purposes equals the liberal capitalism or market liberalism of the nineteenth century.

91 www.business-humanrights.org/media/documents/ruggie/applications-of-framework-2-may-2011.pdf (last accessed 03.09.2011).

92 Resolution: Human Rights and Transnational Corporations and Other Business Enterprises, 16 June 2011 (UN Doc. A/HRC/RES/17/4).

93 Baars, Law Congealing Capitalism, n. 53 above.

94 See also, G Baars, "International law and the encoding of empire's privatisation", Critical Approaches to International Law Conference "The Force of International Law", Birkbeck College, London, 15-17 May 2006; and see, e.g., M Koskenniemi, "The fate of public international law: between technique and politics" (2007) 70(January) Modern Law Review 1.

95 On this notion, see also G Mundlak, "Industrial citizenship, social citizenship, corporate citizenship: I just want my wages” (2007) 8 Theoretical Inquiries in Law 719, p. 745.

96 D Harvey, The New Imperialism (Oxford: OUP 2003), pp. $137 \mathrm{ff}$.

97 Baars, Law Congealing Capitalism, n. 53 above.

98 D Harvey, A Brief History of Neoliberalism (Oxford: OUP 2005). See also A Ong, Neoliberalism as Exception: Mutations in citizenship and sovereignty (Durham: Duke UP 2006).

99 Harvey, A Brief History, n. 98 above, p. 3. 
What is "new" about neoliberalism is the very fact that it has come after a failed embedded liberalism. This aspect should not be underestimated, in particular for its ideological significance. 100 It allows an "end of history" discourse as well as the assertion that "there is no alternative". ${ }^{101}$ A key element of neoliberalism (and indeed liberalism in general) 102 is consent by the governed. ${ }^{103}$ In his 1982 article, Ruggie looked at "how power and legitimate social purpose become fused to project political authority into the international system". ${ }^{104}$

Likewise, Ruggie's business and human rights project is seeking to rehabilitate the multinational corporations, after the backlash, by instilling them with a legitimate social purpose (CSR) while at the same time allowing them (or rather, individual businesspeople through them) to exert authority on the global level. One way this authority is achieved is through (incrementally) fundamentally changing the way lawyers view law (which may have been partly the reason that Ruggie, an international relations scholar, was appointed as an expert on a human rights issue) - asserting that on the international level, we have "no international government" but instead "governance" which is a "dynamic interplay between civil society, business and the public sector". 105

This aspect in particular is picked up by Ronen Shamir in his analyses of the CSR field. Another is that of the "market-embedded morality."

\section{Ronen Shamir: towards a market-embedded morality? A critique of corporate social responsibility}

In a series of articles and book chapters, Ronen Shamir critiques the field of CSR. ${ }^{106}$ CSR, according to Shamir, is the corporate response to the global backlash also mentioned by Ruggie, but with a particular dimension that makes it relevant to this discussion. Shamir asserts that the CSR regime was designed in particular to ward off legal activism from those seeking corporate accountability through either accountability lawsuits (e.g. through the US Alien Tort Claims Act) or the production of blueprints for the legal regulation of corporate responsibility. ${ }^{107}$ This phenomenon itself shows a remarkable inversion, where law becomes the "sword" of choice for members of civil society who until recently mainly used law as a "shield", while the elite used law to constitute, entrench and protect its interests. It

100 In the seemingly endless cycle of liberalisms, it is now being suggested that "neoliberalism's failures" can be met with a "counter-hegemonic globalization", defined as a "globally organized project of transformation aimed at replacing the dominant (hegemonic) regime with one that maximises democratic political control and makes the equitable development of human capabilities and environmental statements its priorities": P Evans, "Is an alternative globalization possible?" (2008) 36(June) Politics and Society 271.

101 As used by Frances Fukuyama in The End of History and the Last Man (New York: Free Press 1992), and British Prime Minister David Cameron, respectively: "David Cameron: cuts won't be easy but there is no alternative", The Guardian, 6 October 2010 (reporting on the 2010 Conservative Party Conference).

102 Pre-liberal capitalist orders relied pre-eminently on coercion, while liberal orders to some extent are able to replace coercion with consent by "manufacturing consent" ( $\mathrm{N}$ Chomsky, Manufacturing Consent: The political economy of the mass media (London: Vintage Books 2006) and creating “docile bodies" (M Foucault, Discipline and Punish: The birth of the prison (London: Vintage Books 1995).

103 Harvey, A Brief History, n. 98 above, pp. $39 \mathrm{ff}$.

104 Ruggie, "International regimes", n. 71 above, p. 382.

105 Ruggie, "Taking embedded liberalism global", n. 81 above, p. 232.

106 R Shamir, "Corporate social responsibility: a case of hegemony and counter-hegemony” in B De Sousa Santos and C Rodriguez-Garavito (eds), Law and Globalization from Below: Towards a cosmopolitan legality (Cambridge: CUP 2005), pp. 94, 531-53; “Corporate social responsibility: towards a new market-embedded morality?” (2008) 9 Theoretical Inquiries in Law 32; "Between self-regulation and the alien tort claims act: on the contested concept of corporate social responsibility" (2004) 38 Law and Society Review 635; "Capitalism, governance and authority: the case of corporate social responsibility" (2010) 6 Annual Review of Law Social Science, pp. 531-53.

107 Shamir, "Between self-regulation", n. 106 above, p. 636. 
is therefore not surprising that the corporate response is to break the "sword" by insisting on a notion of CSR as an "essentially voluntary and non-enforceable issue". ${ }^{108}$

The strategic move by businesspeople in this "field of contention" has been "to become actively involved in various displays of corporate responsibility". ${ }^{109}$ The effect has been the privatisation of regulatory structures - with businesspeople being able to define (and diffuse) the limits of their own responsibility through layering onto the legal corporation construct various voluntary guidelines, while looking good doing it. Having set the parameters, a trend toward the legalisation ${ }^{110}$ of CSR forms no threat to the businessperson - on the contrary, concealed from view, she or he can now use the lower standard congealing into law to "level the playing field" with competitors and activists alike. As in the example of the struggle over the working day, resistance is domesticated by legal compromise. And, as in the working day example, enforcement necessitates a whole new struggle, involving representation, middlemen and women, institutional and systemic constraints.

Shamir asserts that "an intense interest in ethics and morality has mushroomed alongside the triumphant ascendance of market rationality as a general principle for conducting social relations". 111 At the same time, "[a]uthority itself is being privatized, transforming rules in general and public policies in particular into commodities that are produced, distributed, and consumed by a host of agencies, enterprises, and non-profit organizations". ${ }^{112}$ Rather than a re-embedding of the market in society, Shamir finds:

[T] he discourse and practice of business and morality is a product of the neoliberal project of dissolving the epistemological distinction between market and society. The greater the drive to embed society in the market, the more sociomoral questions ... become reframed from within the market. ${ }^{113}$

This (false) synthesis between economy and morality "further consolidates, rather than undermines, the neo-liberal social order". ${ }^{114}$

How did this situation come to be? Shamir argues that the collapse of welfare-state liberalism brought into being a neoliberal order governed through a "market of authorities", where the state is no longer the sole or main site for the production of legitimacy, where law becomes a "shared problem-solving process" and instruments such as guidelines and standards replace much hard law. ${ }^{115}$ Neoliberal responsibilisation is directed at individuals and at institutions including corporations and is based on the model of a rational actor who assesses costs and benefits of his or her actions: who, in other words, makes moral decisions on the basis of the logic of the market. ${ }^{116}$

Assessed from a Marxist perspective, this situation is not new. The "cash nexus" that pervades all relationships including basic human relationships in capitalism means cost/benefit or value calculations are made when deciding upon particular (trans)actions. What is new about neoliberalism viewed from a Marxist perspective is that the "relative autonomy" that was accorded to the state (whether or not this autonomy was real or merely

108 Shamir, "Between self-regulation", n. 106 above, p. 636.

109 Ibid. p. 644.

110 In the sense of codification and adoption in formal legal instruments such as a potential future "CSR treaty".

As noted above, I include CSR and similar norms produced through global governance in "bourgeois law" in

Pashukanis' sense.

111 Shamir, "Corporate social responsibility", n. 106 above, p. 372.

112 Ibid. p. 372.

113 Ibid. p. 373.

114 Ibid. p. 374.

115 Ibid. pp. 378-9.

116 Ibid. p. 380. 
ideological) ${ }^{117}$ is now in the process of disappearing. While before, states may have produced class law, now, class law is produced directly by the capitalist class without the mediation of the state.

Moreover, the effect of responsibilisation is that we perceive this state of affairs as legitimate. Consciously or otherwise, the discourse of those making moral claims of market actors (NGOs, cause lawyers, activists) forms a constitutive element of the structure it is seeking to subvert. ${ }^{118}$ On top of this:

[o]nce all players involved, namely national governments, global institutions, corporations, and civil society organizations, share the private regulation approach within the broader governance matrix, a whole new set of questions arises concerning the conditions for the perception, articulation and creation of socio-moral sensibilities and their translation into concrete political action. ${ }^{119}$

Henceforth, "welfare-governance" is articulated according to the logic of the market and "de facto 'cancel[s]' any notion of contestation between social interests and economic imperatives". ${ }^{120}$ Moral considerations lose their transcendental value and re-emerge as business opportunities. ${ }^{121}$

Shamir highlights the "adaptability" of capitalism that Rosa Luxemburg analysed in "Reform or revolution".122 Moreover, Shamir demonstrates there is no in-between, between the market and "post-capitalism". What we view as "embedded liberalism" is in fact "market-embedded morality" or neoliberalism, which is classical liberal capitalism.

\section{Governance: society, class, or global domain?}

One main weakness of Polanyi's theory is precisely this lack of a clear separation between the "sein" and the "sollen": the "is" and the "ought". 123 The idea that a self-regulating market ("market society") cannot exist rests on the assumption that "society" can and will prevent this, based on a sense that the destruction brought about by market society is wrong, undesirable. Likewise Marx's concept of class struggle relies on the idea that the worker/the working class know (and feel) themselves to be exploited and in due course gain class consciousness and seek to come out from under the yoke of capitalism through revolution. Both are rather significant assumptions to make but empirical reality points towards a greater likelihood of the (vastly larger) exploited class struggling to better their situation, than it does to "society as a whole" seeking to remedy the negative effects of the market when, for some, the positive effects clearly outweigh the negative.

117 On this notion, see L Althusser, "Contradiction and overdetermination" in F Maspero (ed.), B Brewster (trans.), For Marx (New York: Random House 1969), pp. 87-128.

118 Shamir, "Corporate social responsibility", n. 106 above, p. 388

119 Ibid. p. 389. On the notion of governance and related points in more detail, see also Shamir, "Capitalism, governance and authority", n. 106 above.

120 Shamir, "Corporate social responsibility", n. 106 above, p. 389.

121 Ibid. p. 394.

122 Rosa Luxemburg argues that those measures of capitalist “adaptation" cited by Bernstein, e.g., the development of a credit system, in fact confirm Marx's theory of crisis because such adaptations flow out of, and in fact exacerbate, capitalism's inner contradictions and move capitalism towards its inevitable collapse (Luxemburg, "Reform or revolution”, n. 3 above, pp. 47-55). See also, Marx and Engels, Manifesto, n. 36 above, pp. $45 \mathrm{ff}, 60$.

123 I use this not in the strict Kelsenian legal sense but in the general sense of the conflation of fact and norm, or, perhaps in this case more accurately, the fact and the wish or moral sentiment. 
Polanyi is by no means unaware of class, making frequent reference to "the common people" and their character, and role in society. ${ }^{124}$ As Polanyi sees "society" rising up to protect itself, what does he mean by "society", or, what (section of) society would have been "springing up" in the particular historical conjunctures described by Polanyi? At the time of Speenhamland this was the squirearchy, though after the Reform Act and the completion of the transition to capitalism, the society that was "discovered" was the bourgeoisie.

In line with Marxism's internationalism, the notion of global classes has recently been elaborated in legal scholarship by among others B S Chimni: "the "transnational capitalist class' (TCC) operates in the transnational public sphere and drives globalization in both the developed and third world countries". ${ }^{125}$ Ruggie's concept of the "global domain" where civil society, business and states are the norm-creators is clearly a connected notion, albeit perceived from a different ideological standpoint. Ruggie argues that "[a] global public domain is emerging which cannot substitute for effective action by states but may help produce it". ${ }^{126}$ Shamir's conception of governance is a stronger version of the same idea.

That Ruggie approximates Shamir's horizontal governance "market of authorities" (where the TCC rule) is implicit in his closing observations:

[t] he very different dynamic at work now compared with the 1980s is that business wants to help channel some of the pressures it faces into the construction of at least minimally effective public sectors, including at the global level. ${ }^{127}$

What we have, then, is a "fundamental recalibration of the public-private sector balance". ${ }^{128}$ In other words, the contemporary analysts appear to agree in general terms on the current configuration of the global order - which leaves us only the final question: what is to be done?

\section{Conclusion: market or revolution?}

Finally, I now return to Rosa Luxemburg and this article's title, "Reform or revolution?", for a conclusion on the regulation of the economy, through law. Luxemburg's own position on the issue is implied here:

No law obliges the proletariat to submit itself to the yoke of capitalism. Poverty, the lack of means of production, obliges the proletariat to submit itself to the yoke of capitalism. And no law in the world can give to the proletariat the means of production while it remains in the framework of bourgeois society, for not laws but economic development have torn the means of production from the producers' possession. ${ }^{129}$

Of course, for Rosa Luxemburg, to reform or revolt is not a matter of choice, as revolution is inevitable:

The scientific basis of socialism rests, as is well known, on three principal results of capitalist development. First, on the growing anarchy of capitalist economy, leading inevitably to its ruin. Second, on the progressive socialisation of the process of production, which creates the germs of the future social order. And

124 In addition, Polanyi sees the division of labour being a result of biological (e.g. sex) and geographical factors.

125 B S Chimni, "Prolegomena to a class approach to international law" (2010) 21 EJIL 57, and the response to this article, A Rasulov, "Bringing class back into international law", 6 September 2008, available at SSRN: http://ssrn.com/abstract=1675447 (last accessed 9 May 2011).

126 Ruggie, "Taking embedded liberalism global”, n. 81 above, p. 232.

127 Ibid. p. 252 (emphasis added).

128 Ibid. p. 253.

129 Luxemburg, "Reform or revolution", n. 3 above, p. 92. 
third, on the increased organisation and consciousness of the proletarian class, which constitutes the active factor in the coming revolution. ${ }^{130}$

"Market-embedded morality" and class law produced through global governance contributes to "the growing anarchy of the economy" - and thus to capitalism's end. When this moment arrives, Marxists envisage capitalism's replacement by a "dictatorship of the proletariat" as a temporary phase before the state withers away and we achieve communism. ${ }^{131}$ The idea is that law, too, will wither away, leaving just such "technical regulation" as is necessary for the practical, logistical organisation of society. Such regulation differs from law in its "unity of purpose", as opposed to law, which is based on disunity of purpose or contestation. ${ }^{132}$ Production and distribution will be organised, not on the basis of "equal rights", but on the basis of "from each according to his ability, to each according to his needs!"133

Polanyi emphasises that we need control and legal regulation to ensure, in particular, "freedom".134 Communist society envisages emancipation from law: instead of "legal emancipation" - which is the abstract equality enjoyed by the citizen as legal subject: "buman emancipation" we achieve:

[o]nly when the real, individual man re-absorbs in himself the abstract citizen, and as an individual human being has become a species-being in his everyday life, in his particular work, and in his particular situation, only when man has recognised and organised his "forces propres" as social forces, and consequently no longer separates social power from himself in the shape of political power, only then will human emancipation have been accomplished. ${ }^{135}$

Besides "rights", "justice" is another concept which in Marxism is associated with liberalism. ${ }^{136}$ Neither are part of the vision, encapsulated in Aristotle's adage, "Where people are in Friendship Justice is not required."137

With the aid of the concept of "market-embedded morality", Shamir has shown us, that the dichotomy between liberal capitalism and embedded liberalism is a false one. Combined with Pashukanis' commodity form theory of law, we can conclude that taming the market through legal regulation is a structural impossibility. This being the case, Rosa Luxemburg's equation of the question of "Reform or revolution?" with "To be or not to be?"138 is once again salient.

130 E.g. Marx and Engels, Manifesto, n. 36 above, p. 60; Luxemburg, "Reform or revolution", n. 3 above, p. 45. On this, in general and on the failure of this process in the example of the Soviet Union, see Sharlet et al., "Introduction" in Selected Writings on Soviet Law and Marxism, n. 50 above, especially pp. xii-xx.

131 See, generally, e.g. V I Lenin, The State and Revolution (New York: International Publishers 1932); see also, generally, Marx, "Critique of the Gotha programme", n. 58 above.

132 Pashukanis, Law and Marxism, n. 45 above.

133 Marx, "Critique of the Gotha programme", n. 58 above, p. 615.

134 Ironically, Polanyi cites this phrase without attributing it to Rosa Luxemburg, "Freiheit ist immer die Freiheit des Andersdenkenden": R Luxemburg, Die russische Revolution. Eine kritische Würdigung (Berlin 1920), S. 109; Rosa Luxemburg, Gesammelte Werke Band 4, S. 359, Anmerkung 3 (Berlin: Dietz Verlag 1983).

135 K. Marx, "On the Jewish Question" in D McLellan (ed.), n. 58 above, p. 64. Another attractive description of emancipated post-capitalism can be found in O Wilde, "The soul of man under socialism" in The Complete Works of Oscar Wilde (London: Book Club Associates 1978), pp. 1079-104.

136 See also C Douzinas, "Adikia: on communism and rights" in S Zizek and C Douzinas (eds), The Idea of Communism (London: Verso 2010), p. 95.

137 Aristotle, Ethics, Book VIII.

138 Luxemburg, "Reform or revolution", n. 3 above, p. 42. 
